\title{
Where, man? - Whitman!
}

Om „Crossing Brooklyn Ferry“ I

\section{SVEND ERIK LARSEN}

Overfart og overgang

Det er helt klart hvor digtet „Crossing Brookly Ferry" foregår: mellem Long Island og Manhattan USA på færgen fyldt med folk der vender hjem fra jobbet. Og de mange opregninger af konkrete ting og lokaliteter omkring Manhattan gør stedet tykt af stedsbestemt, sanseligt nærvær. Her er gader, skibe, master, tåge, måger, søfolk osv. - Men Whitman er mere på farten end på pletten. Digtets oprindelige titel, ,Sun-Down Poem“" havde saledes med tid at gøre, en overgngsfase $i$ tiden bestemt of naturens geng men

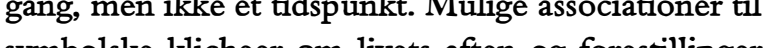
symbolske licher on livets aften og forestillinger om romantiske panoramar udnytres dog the i digtet. Să maske derfor fik digtet sin endelige titel med henvisning, ikke til tid men til en lokalitet, dog mindre knyttet til et afgrænset sted end til en overgang i rum, nu bestemt af samfundets og ikke af naturens gang: transport hjem fra arbejde, væk fra hverdagens sociale rutiner og kun akkompagneret af naturens tidsrytme, „flood-tide below me!“ (v. I).

Socialt rum, naturligt rum; naturlig tid, social tid; fysisk rum og tid, symbolsk rum og tid - kategorierne blandes og overlejrer hinanden. Men der er ikke tale om en koncentration i tid og rum til ét komplekst system som en art mytisk al-tid. Vi moder snare en oplosende manfoldighed of nindider share en oplosende men ( $(v, 20,53-56)$. Ogsa af place " (v. 20, J3-s6). Ogsa afstand oph aves: ",istance avails not (v. 20,56), og uden afstand er vi stedløse. For afstand er jo rumlig udstrækning opfattet $\mathrm{i}$ forhold til den tid vi bruger til at overskride den. Vores tilstedeværelse bliver porøs.

Selv om Whitmans digte fylder tid og rum med konkret stoflighed og massiv tilstedeværelse af men-

PASSAGE 3I/32- I999 nesker og et højeksponeret Jeg, så sætter de først og fremmest rum, tid og subjektivitet i bevægelse. Whitman skriver ikke om noget der $e r$, men om noget der bliver til. Til hvad vides ikke så nøje, og det kommer man kun til at vide ved at deltage i tilblivelsen og forme og formulere overgangene mellem faser og niveauer. Trods Whitmans alenlange kataloger fortæller eller afbilder hans digtning ikke det de benævner, men deltager i den proces de udgør. Det har han læst i Ralph Waldo Emersons, The Poet“ (r84) og snuset til hos Wilhelm von Humthe (184) og suramCouropæisk også er to egriber en moderne sproghandingsanalyse: "Ord er også handlinger, og handlinger er en slags ord" (Emerson 198r: 244). Grundtvigs 'ordet skaber hvad det nævner' kunne han jo af gode grunde ikke kende, men tankegangen kender han. ${ }^{2}$

Det skabende ord er ikke en individuel men en national forpligtelse, idet nation for Whitman, især i programskriftet „Democratic Vistas“ (1867/1871), ikke så meget er et sted men et princip: det amerikanske demolrati. Digteren skal gennem sine ord holde den demokratiske bevidsthed aben i rum og tid, siger Whitman i besværgende gentagelser:

Den oploftende og overjordiske ide om det ukendte og det uvirkelige skal fremfores med autoritet, fordi de er det kendtes og virkeliges legitime arvinger og mindst lige så store som deres ophav. [...] Som olien giver næring til flammen og flammen til himlen, således må velstand, videnskkab, materialisme ja endog det demokrati vi bryster os sådan af, uafvendeligt give nering til den hojeste bevidsthed, sjelen. 
Skont Whitman er knyttet til et bestemt sted, USA, med hud og hår, næb og klør, ord og sansning, er han samtidig bestandigt på vej væk fra ethvert statisk udgangspunkt. Det kendte åbnes mod det ukendte; det er ikke det ukendte der reduceres til det kendte $i$ en fortsat national selvlegitimering. Han beveger sig fra USAs natur og samfund mod globalt fallesskab; fra den givne tid og det opod globalt follestik ojeblik mod frighed; fa det enkelt Jeg's kn, krop og bevidsthed mod et $\mathrm{D}$ der omfatter alle fra det enkelte medmenneske den ganske menneskehed (cf. Greenspan 1990), således i digtet "On Journeys“:

On journeys through the States we start, (Ay through the world, urged by these songs, Sailing henceforth to every land, to every sea, We willing leamers of all, teachers of all, and lovers of all

På rejser gennem Staterne begynder vì (Åhja, gennem verden, drevet af disse sange, sejlende fra nu af til hvert land, hvert havi) vi der villigt lerer alt, laerer alt fra os, og.elsker alt

Det er Whitman der selv skaber dette „we" i digtet, f.eks. i det ene af digtene kaldt „To you“ hvor 'ord er handling':

Hvem du end er, nu legger jeg min hånd på dig, så du kan blive mit digt

(Whitman I990: I86)

Hele bevægeligheden udfoldes $i$ en flydende retorisk og rytmisk sprogproces. Den sørger for at perspektivudvidelsen er brudløs og hverken fremstår som en abrupt overgang, et diskontinuert spring, fra det afgræensede sted til det unomert spring, det afras kosmos eller fra Jeg til Du, eller primært fokuserer på et om fattende mal, en utopisk ide. Hele tiden fastholde den konkrete opmærksomhed på vejen derhe skridt for skridt, omend nogle gange med syvmile

Det er imidlertid ikke blot teksterne selv der virker ved deres materielle og sanselige fremadskriden den erfaringdannelse de beskæftiger sig med, hvor vidtloftig den end måtte være, slipper aldrig fortøjningen $i$ en sansebàren ekspansionsproces. Whitman skriver ikke universalpoesi $i$ en transcendental idealismes navn, men globalpoesi der indkapsles $i$ en materialistisk idealisme eller romantisk naturalisme, hvis vi ved denne storrelse forstå fer om fet naturlige eller, med , at opnå en følelsesmæssigt tilfredstillende 列 det iøjnefaldende og det mystiske" (Fairschild r96r:

am with you, you men and women of a generation, or ever so many generations hence (V. 2I),

men på denne betingelse:

I too had receiv'd identity by my body

That I was I knew was of my body and what I should be I

knew I should be of my body (v. 64)

Digtene er derfor ikke præget af metaforiske og symbolske synteser, hvor de integrerede elementer forenes $i$ én fællles betydning. De er domineret af metonymiske kombinationer, hvor delelementer sideordnes eller indsattes $i$ helheder uden at miste deres eget, sanselige særpræg (cf. Hollis 1983: ch. V):

The simple, compact, well-join'd scheme, myself disintegrated, every one disintegrated yet part of the scheme $(v .7)$

Just as you feel when you look on the river and sky, so I felt Just as any of you is one of a living crowd, I was one of a crowd,

Just as you are refresh'd by the gladness of the river and the bright flow, I was refresh'

Just as you stand and lean on the rail, yet hurry with the

swift current, I stood yet was hurried (v. 22-25)

Den lyriske prosa og prosaiske lyrik holder netop teksternes skabende og modtagende subjekter fast $\mathrm{i}$ den permanente overgangstilstand mellem de modsætninger i rum, tid og subjektive positioner som formes $i$ teksterne, og som gøres nærværende i og med teksterne.

Den amerikaniserede polske greve Adam Gurowski noterer om USA og Whitman i sin dagbog i 1866: „Vi er $i$ en overgangssituation, siger mange amerikanere, nogle of dem de mest ophojede, origiamerikanere, nogle af den de mest ophøjede, originale og ægte amerile disse er digteren Walt Whitman" (cit. efter Greenspan 1990: 136). Notatet er skrevet oven på Borgerkrigen, men endnu inden den forste efterkrigsudgave af Leaves of Grass kom på gaden i 1867 og "Democratic Vistas"i r867/1871. Det rummer antebellum forestillinger om det genuint nationale, men også de nationale tømmermænds behov for efter krigen at få klare og styrkende fortolkninger af uvisse forandringer og overgange - deltager amerikanerne i fremskridt, demokratiets fødsel, frihedens sejr, naturprocessers fremadskriden, social omvæltning, undertrykkelse, social opløsning, moralsk forfald, sprogets fornyelse eller hvad? Det er $i$ dette ibne felt af ore åbne felt af overgange Walt Whitmans digtning befinder sig, store follessyne holdes op mod det udsatte enkeltindivid der skal bære dem: "Jeg vil ikke sove længere men rejse mig" (Whitman 1990: 28, cf. Whitman 1965: 516)

\section{Europa og det nationale sted}

Der er selvfølgelig ingen tvivl om at Whitman, trods kosmologiske armsving, er en national poet, der hymnisk svøber USA ind i ord der gør dette sted til ikke bare hans sted, men stedernes sted, f.eks. i digte som „By Blue Ontario's Shore“, , Salut au monde!“, „Starting from Paumanok" eller "Our Old Feuill gre“. I omfattende katalorer op "Our Whitm og deres forunderlige of forbilledlige demokratiske

En sådan national stedsfølelse anslår andre strenge end den europæiske, f.eks. i H.C. Ørsteds opfattelse af danskhed i 1836 :

Hvori bestaaer da Danskheden? Først indbefatter den, som enhver Nationalcharakteer, alt det, som udgøør Menneskevesenet; men det som giør denne Charakteer til den danske, er na- turligviis Summen af de Trak, som hyppigere forekomme hos vort Folk end hos de øvrige. [...] Det danske Land har en venlig Natur, det Store aabenbarer sig sjeldent der uden $\mathrm{i}$ Himmel og Hav, og det Skrekkelige er nesten udelukt derfra; [...] Omgivet af denne Natur har Folket nu levet og udviklet sig i Orth

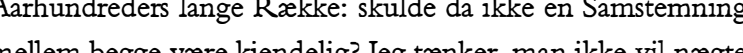
Dancen, at her god Darken, at here godien Vold og til Ranker, jelden hetig 1 sine Lidenskaber. [... Vilde nogen spørge mig: hvorledes kommer man til at skrive gte Dansk? vilde jeg omtrent give samme Svar, som hvis han spurgte mig: hyorledes bliver jeg æagte Dansk i hele mit Sind g mit Vesen? Jeg vilde nemlig sige ham, folg din Natur med ormutt: naar en Dansk, som er født og opdragen blandt Danske og har levet blandt dem, folger denne Forskrift, bliver han uden videre ægte Dansk; kun ved Kunstleri afviger han fra Danskheden. (Ørsted I852: 50-53)

Mere end en opfattelse af hvad en nation og en naionalkarakter er, formulerer Ørsted en opfittelse af ived er, det rette hjemsted. Det er opinde et folk og (t) med gransen, man ender ved centrum; med sproget, man ender ved landskabet, med landskabet, man ender ved folket; med folket, man ender ved stedet. Den stabile treklang af landskab, menneske og sprog, der giver et sted en immanent identitet, er kernen $i$ det 19 . århundredes europæiske nationalitetsforestilling, også når den kritiseres.

Den hviler på to underforståede forudsætninger. Den ene er at enheden af de tre elementer skyldes at de under ét er i skarp kontrast til det fremmede og anderledes, til „Kunstleri“", hvad enten det drejer ig om en anden nation eller den kulturlose og der-

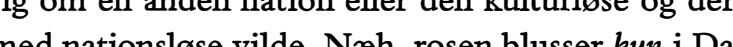
a (n) ing klart fendebillede, og John Dryden, vist nok som den forste, lagde i renassancen med udtryket "the noble savage" (cf. Fairschild 196r: 29) op til at sentimentalisere forskelligheden. Siden har denne blanding af skræk og føleri under ét berøvet det fremmede dets selvstændighed og legitimeret allehånd forsøg på, fysisk eller symbolsk, at reducere det til 
det kendte eller at negligere det, en problemstilling som hele den post-koloniale diskussion har givet ny aktualitet. Denne bevægelse er den stik modsatte af cratic Vista", femeger at det kende og venocratic Vistas skal føde det ukendte og uvirkelige som er "mindst lige så store som deres ophav" (Whitman 1965: 538 ).

Den anden forudsætning er at denne nationalitetsforstålse fastholder en før-moderne opfattelse af sted, kendt tilbage fra Aristoteles' fysik: alle ting hører til på et sted, deres rette sted, i den kosmiske orden (cf. Aristoteles 1930, Lang 1995): Slipper man en sten, anfører Aristoteles i sin etik, falder den til jorden, om man så kastede den ro.ooo gange op i luften til den flyvende Moerlille (Aristoteles Igrs: IIO3b). Ting er i hvile på det rette sted i kraft af deres natur. Er de dog $i$ bevægelse $i$ forhold til dette res natur. Er de dog i beragelse i foritd dil dette forandring, som organismer, og er så på vej til at være $i$ hvile pá et andet sted der nu er blevet det rette. Eller de kan være påvirket af ydre faktorer, der stammer fra ting der selv kan forstas ud fa hvad der måtte være deres rette sted. Ting der ser ud til at være i hvile, kan altså være det forkerte sted. Bestemmelsen af det rette sted kræver derfor en videnskabelig håndsrækning.

Men uanset hvordan, så har mennesker, også ting, og især steder en skytsånd, en daimon eller en genius, der beskytter deres indre væsen eller særpræg, et indre kompas der styrer dem mod de steder de hører til, og som, i skikkelse af en genius loci, giver steder et anleg for at vare de rette steder for vise ting og et anlag for at vare de rette steder for visse ting og ilke for telse forudsætter en gensidighed mellem ting og sted, mennesker og sted, der specifcerer begge. En genius loci udtrykker denne gensidighed. Det danske landskab er til danskere, og danskerne er til det danske landskab, hævder Ørsted, og det danske sprog giver denne gensidighed kommunikativ form så den kan blive til falles kultur.

$\mathrm{Nu}$ er den europæiske nationalismes forestilling om en stabil og århundredlang syntese mellem natur, folk og sprog og om det rette sted med rod i naturen jo en kulturel konstruktion. En nyttig kon- struktion, må man tilføje, der tjener til at mobilisere kollektiv og individuel identitetsdannelse pà bestemte historiske vilkar. Den forholder sig dog ret vilkårligt til historiens mas irer men mytogiseris. For de europæiske nationer der er institutionaliseret som nationalstater, er jo ikke enheder og slet ikke oprindelige, men er rester af en række sammenbrudte imperier, sørgelige rester mente de fleste bare 30 år før Ørsteds nationale naturalisering, da København blev bombet og kæden sprang af det danske imperium. Enhedskonstruktionen holder sammen på resterne, så opløsningen bliver til at bære.

Ejheller den klassiske opfattelse af sted er $i$ trit med de faktiske forhold i jernindustrien. Ja, faktisk hviler hele mationens sociale og akonomiske udvik作

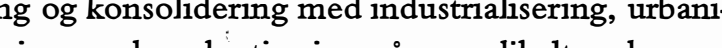
作 $m$ end den som den nationale selvdefinition promoverer. De moderne naturvidens les (Galilei 1962), bombede den klassiske gensidig hed mellem ting og sted lige så effektivt som engænderne København og nordstaterne Atlanta og sendte genius loci $\mathrm{i}$ eksil.

For det første indebar det naturvidenskabelige eksperiment at ting faktisk blev studeret bedst, når de blev flyttet til et andet sted end deres rette sted: de blev sønderdelt, flyttet til laboratorium, udsat for variable eksistensbetingelser, blev smidt ud fra kavie farne-osv. For det andet medforte formule ingerte formule作 pat samme måde, uanset hvad slags ting de er, og tanset hror de in $i$ rette steder, og $\mathrm{i}$ forhold til faldlovene er der ingening der er mere natur end andet. En sten falder ikke mere naturligt end en colaflaske.

Et begreb om et abstrakt rum der, som hos Isaac Newton, er defineret som medium for naturlovene uafhængigt af tid og tilstedeværelse af ting, erstatter begrebet om stedet og dets genius der garanterer en stabil orden. På græsk og latin er de rumlige begreber knyttet til steder, dvs. dér hvor noget er til stede (topos, chora, locus) eller til afstande mellem så- danne steder (dialeimma, spatium). Men det abstrakte rum er ikke knyttet til en tilstedeværelse. Ting har derfor ikke et rette sted, men kan anbringes po t vilko̊rligt sted, hris det menos bringes pat subjekt en entrollere naturlovene. tonske rum er at det ekspansive, individuelle subjek placeres i centrum og dér eksperimenterer med beregninger og kontrol. Når det abstrakte rum konkretiseres i menneskelig øjenhøjde som renæssancens centralperspektiviske rum eller som den teknologisk beherskede fysiske natur, er det derfor to sider af samme sag, for dette rum frisætter menneskelig magt til at danne og opleve ting på egne betingelser.

På den baggrund bliver naturhistorie og teknologihistorie ét og det samme, mente Francis Bacon alerede $i$ i 626 , og noterede at mennesket derfor lerede 1626 og no kunne over 列 ret størrelsen af:

Men den person der kender former opfatter Naturens enhed i substanser der er radikalt forskellige fra hinanden, og kan derfor opdage og frembringe virkninger der aldrig for har veret frembragt. [...] som nogle af de opfindelser der allerede er gjort, har været af en sådan slags at ingen, før de var opfundet, ville være have fâet den ringeste ide om dem; de ville hånligt have anset dem for umulige. [...] Da skal vi ikke lengere springe omkring i små cirkler som forheksede mennesker, men skal i vores rekkkevidde måle os med den ganske verden. (Bacon 1994: I35, Ir3)

For Bacon betyder 'former' her ikke essenser, som f.eks. den form som Ørsteds danske landskab har. 'Former' er derimod de love, naturlove, der gælder for adskilte legemers indbyrdes påvirkninger. Det sted der beskrives her, er derfor ikke den danske muld hror risted turer rund $i$ små forheksede cirkler med sine blide ler rundt i smà forheksede cind stand rummet som stedet for kombination af en uendelig mængde kendte og endnu ikke kendte eller opfundne ting, eksperimenternes rum. Den politionalstaten, men den ganske klode. Og det men- neske der er aktivt her, lever ikke af rødgrød med fløde og synger ikke efter Højskolesangbogen, men er den kosmopolit der har faet sin definition i Oplysningstiden, synger om frihed, lighed og broderhe hedserklæring: Dette menneske tænker mere på industrialisering, internationalisering og eksport
end på Dybbøl Mølle, Dannevirke og de tabte hertugdømmer.

Whitman og det nationale sted

Det er dette eksperimenterende menneske Whitman er solidarisk med, og hvis sted han, især i „,Democratic Vistas" (1867/I87I), ser som et USA der er forskelligt fra Europa, en kontrast der trækkes frem $i$ de fleste amerikanske formuleringer af nationalt særpræg. Det ser jo umiddelbart noget selvmodsigende ud. fallesskab baseret på et ekspansivt individ i konstant bevage, lokaliseret på et sted der skal i vare alle steder Deter en modigle. Og deter den deri hans digte optreder som ove Oge par den der 1 hans dige optrader som ove Onge pa mange nivear og ater opfatelsen af forholdet mellem sted, subjekt og sprog til mere udsatte egne end de hjemlige dalstrog og flodbredder. Hans nationale begejstring for "disse staters ånd“" og "vort lands ånd“" (Whitman 1965: 512, 518) står ganske vist pà overfladen ikke tilbage for hvad europæiske chauvinister kan mobilisere, og de sproglige guirlander de smykker hans nationale templer er ikke så forskellige fra europæernes at det gør noget. Trods den ofte skarpe markering af forskellen mellem Europa og USA som afsæt for definition af amerikansk identitet, som f.eks. i Frederick Jackson Turners Frontierideologi, er den europmiske nationalisme jo beller ikke fremmed som model for amerikansk tankegan og (g9, Shumby 1098). Og af nogle er ogs Whitman blet rellet id i Stas and Steses (feks. Knater Knapp 1993). Alligevel er der ikke meget europæisk "Het-har-hjertet-hjemme nationalisme over Whit"Lans selvpejling i digte om "Nationernes nation ", land ", „I enhver periode ma ét land føre an “, „Ideen om fuldkomne og frie individer", „De mokrati [...] der dækker verden" o.l. (Whitman I990: 266ff) 
Lad mig, primært med reference til „Crossing Brooklyn Ferry", markere nogle modsætninger til den europæiske treklang: landskab, sprog og folk Digtets første verbum er „see“ (v. I), der giver alle muligheder for at folges op af et panoramisk vue over det nationale landskab: Se dig ud en som over det nationale landskab: "se dig ud en somme dag , ,Jeg se de hat Whan ha ingen panoramaer. Het fren til v. 20 møder vi fo trinsvis bevægelsesverber, der drejer sig om at ove skride stedets grænser: ",cross“, „enter the gates", ,follow“, „rushing", „swimming“, suppleret med substantiver som ,wall"“, ,passage“, „the pouring in", "the falling back", og vi fầ serveret propositionsforbindelser som "from shore to shore", tidsangivelser som "swiftly", ,years hence" og rumangivelser som "far away". Selv verbet "see“ har som objekt bevægelige genstande: „Flood-tide“ Det mest statiske er den gentagne bevægelse: ,returning“, „pouring-in/falling-back“, „flood-tide“, ,usual“. Og er man i ro, så er man i ro på et skib

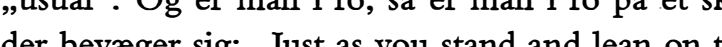
der beveger sige Just as you sand and lean on the rail, yet huny wis he swet was hurried (v. 25), "Be fln, rail over the river, to support those who lean idly, yet haste with the has ting current ( $(v$. Ir3). Fokus er ikke blot labile steder, men selve stedets labilitet. Der er ikke blot tale om færgeoverfart, men der er fart over færgen o over feltet.

På et sådant vibrerende sted er alt en passage og aldrig i hvile på sit rette sted. Der er ingen århundredgammel rodfæstethed, som hos Ørsted, og ingen udvikling eller påvirkning fra fortid til fremtid, men „similitudes" mellem dem (v. 8). Derfor er stedets særpræg heller ikke knyttet til en oprindelig naturgroethed, men bliver til her-og-nu gennem dem der er tilstede og bruger det:

Saw many I loved in the street or ferry-boat or public assembly, yet never told them a word,

Lived the same life with the rest, the same old laughing, gnawing, sleeping,

Play'd the part that still looks back on the actor or actress,

The same old role, the role that is what we make of it, as

great as we like,

Or as small as we like, or both great and small (v. 8r-8s)
På ethvert tilfældigt tidspunkt hvor man er til stede, hersker forskellighedens uopløselige og modsatrettede samtidighed. Denne tendens ytrer sig i Whitmans mange katalog-passager (cf. Coffing I974) og i citatets to sidste vers: vi kan (fore det ene eller det indet, og sker det (inan vi ogsà gøre begge dele på én gang. Det rette sted er det modactede sted. Whitman er derfor mindre i et geografisk rum, et fysisk landskab, end i et socialt og symbolsk rum. Ørsteds rum har naturligvis også sociale og symbolske kvaliteter, men de er forankret på et materielt sted. Det er karakteriseret som det Georg Simmel kalder et eksklusivt rum: det kan kun rumme én af sin slags der har suverænitet over stedet (Simmel I968: kap. 9), dvs. kun én stat, men godt flere trossamfund. Et sådant rum har et orienterende fikspunkt og klare grænser bestemt af ,,slutninger, tollninger og interpolationer" (ib.: 468 ), dvs. grænser der er mere end. blot fysiske.

Denne karakteristik omfatter det nationale landDen katalo landi i Eurap. (Hekten politiske magtkategorier: statsmagt, internationale garantier og konventioner, militær osv.). Det givne rum har ét suverænt folk og former det i overensstemmelse med denne eksklusivitet, som hos $\varnothing_{\mathrm{r}}$ sted: Danmark er for danskere, fordi århundrederne har formet dem således; denne nation har landskabet som sit nødvendige fikspunkt og sproget som garant for danskhedens grænser. Dette rum er grundlaget for de topografiske digtes stedsbeskrivelser. $\mathrm{De}$ ikke blot beskriver steder så de kan genkendes, men tolker dermed verden som en orden af ting pa de rette steder med en genius loci. Grundhet shider de retre seder med den moderne storby $i$ sted i traditionel forstand, uden dog af den grund at ophøre med at være et rumligt fænomen (cf. Johnston 1984), hvorpà ogsà landskabet som vedhæng til den urbane kultur tømmes for stedsbundet betydning (cf. Lorsch 1983).

Det er på disse betingelser Whitman skriver (cf. Boelhower 1984). Det særlige amerikanske rum er ikke-eksklusivt; der er ingen stabile fikspunkter, men et mylder af sprog og dermed fortolkninger.
Derfor har den kategoriale skelnen mellem naturlige og menneskeskabte ting, mellem kendt og fremmed, ingen interesse. Alt og alle har indfødsret, blot de er til stede og virker i deres forskelligartede mangfoldighed:

Just as you feel when you look on the river and sky, so I felt, Just as you fe
$[\cdots]$

Just as you are refresh'd by the gladness of the river and the bright flow, I was refresh'd, [...]

Just as you look on the numberless masts of ships and the thick-stemm'd pipes of steamboats (v. 22-26)

Whitman har heller ikke nogen særlig forkærlighed for et oprindeligt sprog til nationale anliggender: et af de nationale digte hedder "Our Old Feuillage“, mens „Starting from Paumanok" vrimler med ord af blandet sproglig proveniens, og den nationale trosbekendelse på prosa hedder „Democratic Vistas“. I dette vark hedder det direkte at Amerika har endnu ikke skabt noget af moralsk eller kunstnerisk

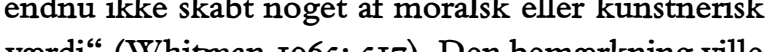
nok have fiet $\varnothing_{\text {rsted til at blegne, havde det drejet }}$ sig om Danmark. Men Whitman ser det anderledes - hvilke muligheder giver det ikke! De stabile grænser, som Ørsted trækker op over for det fremmede „Kunstleri““, er ikke værd at hæfte sig ved:

Thrive, cities - bring your freight, bring your shows, ample and sufficient rivers,

Expand, being than which none else is perhaps more spiritual,

Keep your places, objects than which none else is more lasting (V. 123-I25)

Man kan sige at Whitman ophæver selve stedskarakteren af det sted han henviser til, understreget $i$ sidste citat af at selv når han henviser til et fysisk sted, er det spirituelt, og byen opfordres paradoksalt nok til både at udvide sig og samtidig at holde på de mest varige steder og ting.

Konsekvent vender han derfor blikket mod fremtiden, mod et forestillet rum, et sted der endnu ikke er. Fortiden er blot et logisk nødvendigt eller filosofisk afsæt, men indeholder hverken et selvstændigt attraktivt indhold eller nogen determinerende kraft. Eller erindringen er, som i "Crossing Brooklyn Ferry “, en baglæns repetition af nutiden (afsnit 3). Heri ligger just chancen ,... til at øve lokalsamfund på alle niveauer i selvstyre, begyndende og sluttende igen med de enkelte individer" (Whitman 1965: $504,516)$. Nationen er vehikel for individets selvudfoldelse. Folket er blot det fremtidige, sam selvudfolde kede Amerika (ib.: ST4), endog kaldet „Americanos i „Starting from Paumanok (Whitman 1990: I8ff); de er ikke stoute vikinger der slår hårdt og oplyste bønder der slår rod.

Nationen og dens sted er derfor hos Whitman snarest et begreb, , ,a new standard“ [en ny standard] (Whitman 1965: 524), nemlig om en sted- og tidløs social tilstand, knyttet til det idealistiske, eviggyldige demokrati han ser for sig som en fremtidig realitet, især i „Democratic Vistas“

[Demokrati] er et stort ord hvis historie, tror jeg, stadig er

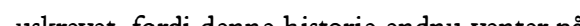
i livet [ ] Amerike der giver sig i kast med at dort ud grundlag [...], må nødvendigvis forkynde sin egen nye stangrundlag $[\ldots]$ (ib.: 516,524$)$

Også Ørsteds opfattelse af nationen er naturligvis baseret på en forestilling om nationens særpræg. Men med referencen til landskabet forankres den pà et sted og $i$ en fysisk realitet hinsides hans egne forestillinger. Landskabet er jo den samme muld og mose da det var Naturens store guddommelige Bog og herremandens eller kongens besiddelse, som nu da det på Ørsteds tid er blevet folkets historiebog og storbondens ejendom. Det er historiens materielle makronbun unset bvilke fysiske mndringer det mentringer det undergar og symbolske projektioner det modtager. om en nation, knyttet til en idé om natur (ib.: 537), kan det kun konkretiseres af det subjekt og i det sprog der udtrykker begrebet og ideen, ikke af de landskab og de steder der forankrer det. Whitmans fremhævelse gennem hele "Democratic Vistas" af a den vigtigste opgave $i$ den unge nation er at fả gode forfattere og god litteratur, er ikke kun selvspejling 
og kunstnermytologi. Det har en undertone af desperat ansvar. For som fremtidig tilstand er der jo ikke andre lokaliseringer af nationens særpræg, end den der ligger $i$ at de enkelte individer bestandig giver det ord. Fremtidens , ,new standard“" ophører jo med at have og få værdi hvis de enkelte individer, som konkrete og leopslige eksistenser her-og-nu, holder op med at holder op med and den kun realtet herigennem. Det er derfor ordene er handing hos. Whim og gor fromiden til "virkelig vision (ib.: s16). Nutens konkete og brogede mangfoldighed, kaldet „stores in advance“ (v. 87), tolkes som fremtidens mulighedsrigdom, men ikke som tilstedeværelse af fremmed "Kunstleri“ der skal beskæres som hos Ørsted. Det eksperimenterende og skabende individ der overskrider grænser, er vigtigere hos Whitman end celebreringen af den kollektive identitet omkring landsbyens gadekær. Det er for lille til Whitmans færge.

Derfor er sprog heller ikke det naturgroede nationale selvudtryk, vokset op af lige dele folkegrund og underorund. Fjheller er det individets suverone undergrnd. Ehollor brogede for brogede forkkellighed. Jeg'et er kun suverænt i forhold til og pa betingelse af et Du der representerer alt det der lis 1983 ):

What thought you have of me now, I had as much of you - I laid in my stores in advance,

I consider'd long and seriously of you before you were born (v. 87f)

Her udveksler Jeg og Du betydning med hinanden formet som tanker, og samtidig konstitueres Jeg og Du derigennem fordi Jeg'et $i$ digtet omsetter digheden til sprog der kan ses og haros. To Jeg' digheden til sprog der kan ses og høres. Tog Jeg'et ikke ordet 1 digtet, ville Jeg'ets foregribende indsats og Du'ets tanke jo forblive uerkendt, eftersom de sker før Du'et er født. Det er denne dobbelte funktion sproget skal tjene: at udveksle betydning og
konstituere subjekter på samme tid, stærkt udtrykt i „To you“"
Jeg synger sangene til ære for ingen, ikke Gud, for jeg synger sangene til din ære. (Whitman 1990: 187)

Før sproget bringes $i$ anvendelse og skaber Jeg og Du og det sted de befinder sig, eksisterer landskab, sprog og subjekter naturligvis som materielle fæno作

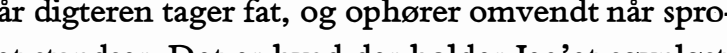
. Brooklyn færgen sejler ikke bare i nat, men hver nat: ,alle den nye nationale virkeligheds ingredienser er] bebudet af min stemme - jeg vil ikke sove længere, men rejse mig" (ib.: 28, cf. især Greenspan 990, men også Hollis 1983) synger Jeg'et $i$ „,Starting from Paumanok".

„Alt sprog befordrer og overfører og er ligesom færger og heste godt til transport, ikke som gårde og huse til beboelse“, kunne Whitman læse i Emersons The Poet" (Emerson 1981: 260). Det lugter både af hverdagsrealitet $i$ sammenligningene og af vision i vercagstealtet i samn 'nligningerne og af vision ' denne sprogproces som tilblivelsesproces der styrer forløbet i „Crossing Brooklyn Ferry“.

\section{Sansning og sprog}

Thomas Man siger det meget præcist i Felix Krull: "For så vidt ordet skal betegne handlinger, er det ligesom en fluesmækker der aldrig rammer" (Mann 1967: 47). Og heldigvis: at ramme vil jo her være det samme som at slå ihjel; måske endda syv i ét slag, som den lille tapre skrædder. At ordet aldrig rammer, betyder at det aldrig overskrider forskellen mellem sprog og virkelighed, men bearbejder den. Det er kun på denne betingelse ordet er med til at tet er kun pà denne betingelse ordet er med til at

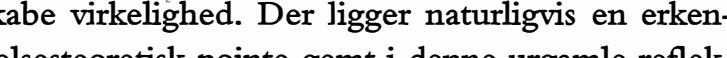
teoretisk pointe gemt i denne urgamle refleksprogets arbitraritet. Men der ligger også en historisk pointe. Og det er den der er relevant os Whitman.

I The Image of the City in Modern Literature (198I) peger Burton Pike på at $i$ løbet af det 19 . århundrede skilles den reale by og den verbale by mere og mere fra hinanden. Pike udtaler sig her netop om en historisk kendsgerning: den arbitrære relation mellem tegn og objekt har antaget former således at den lokalitet hvori tegnene bruges, byen, ikke producere tegn der kan forankres i denne lokalitet. Denne tendens gælder for mere end byen: det gælder for de kultur der, som det USA Whitman forholder sig til formes på urbaringens betingelser, saledes som formes $\mathrm{P}$ a de "Creling Bu dan virelighed forelgger ive bare 1 tid og ru som et genkendeligt sted, men udgør en permanent udfordring: den skal hele tiden erobres $i$ sproget af og for de sprogbrugende subjekter.

Ved siden af modsætningen mellem sprog og virkelighed på urbaniseringens betingelser, er også en anden klassisk modsætning virksom. Modsætningen mellem et sted og dets fysiske kvaliteter og genstande på den ene side og på den anden oplevelsen af stedet $i$ den bevidste eller ubevidste udvælgelse af hvad sanserne opfatter og farver med subjektive forestillinger og værdier (cf. Bàchelard 1958, Cook 1998, Gregory I994 Tuan 1977). Vi kender det fa vidneudsagn til mentale landkort. I Whitmans fifolde skerpes modseng falde skeres iling ins end i hans forestiling, men dog skal fyldes af nutidens konkrete sansede realiteter for at fầ virkelighedskarakter. Mens den første modsætning drejer sig om forholdet mellem sprog og virkelighed, vedrører den sidste forholdet mellem omverden og iagttagelse. Whitman gør begge modsætninger dynamiske ved at de medieres af et subjekt der bliver til i spændingen mellem dem

"Crossing Brooklyn Ferry" handler om denne tilblivelse, og det er den der styrer digtets forløb. Det sker $i$ to faser med afsnit $\zeta$ som omdrejninospunkt. I forste mister den sansede omverden gralvis sine 1 forte mister den sadvis sine subjekt giver den, omvendt kun i medet med de styret af den made dette subjekt bruger sproget på til at give denne verden form. Dermed fảr det selv eksistens som subjekt i forhold til et Du som sproget henvender sig til. Denne eksistens, bundet til Du'et, er den eneste form for eksistens der rækker ud over den eksistens der er knyttet til en ojebliksbestemt sansning af omverdenen. Den første fase bygger således op til den anden. Uden fokus på subjektdannelsen bliver det svært at se at digtets ni dele overhovedet udgør et forløb.

Umiddelbart falder et forløb ikke i øjnene, selv om digtet handler om en overfart: de nummererede afsnit er af forskellig længde og kompleksitet; der er ikke nogen lar lineer fremadshiden, men illagegriberde gentagelser og digressive omveje. Kun en mere overordnet tematis gor et folob synligt. Denne tematik er her jegdannelsen mellem erfaringsdannelse og dialog, udkrystalliseret $i$ to delforløb, ét der har med udviklingen mellem sansning og subjekt at gøre, og ét der vedrører udviklingen mellem sprog og subjekt.

I) sansning og subjekt: Digtet begynder med en sanseregistrering: „Flood-tide below me“ og slutte med mental bevægelse "toward the soul“ (v. I vs v. I32). Selv om sansningen ikke nødvendigvis er sluppet et sted undervejs, er dens fundamentale eller elvfalclige rolle i hvert fald blevet reduceret. Venpeni slutningen af afsnit . s. neskelig kontakt: kroppen alene giver fælles identiet nu og $i$ fremtiden (v. 63-64). Al kontakt mellem Jeg og omverden og andre mennesker foregår gennem sanserne.

Digtet åbner med at Jeg'et ser floden og skyerne $i$ vest og anonyme menneskeskarer. Skønt flod og skyer personificeres, „face to face“ (v. I-2), så står Jeg'et for sig og observerer og er også på afstand af menneskene. De er blot „crowds“, og skønt i fær med en rutine er de lidt fremmede, "curious", for Jeg'et og kræver "meditations“ de selv ingen anelser bor.

Men fra afsnit 2 til slutmingen af afsnit 5 rykker Jeg'et gradvis tættere på ting og mennesker. Det er den ene udvikling $i$ dette forløb. Nærheden øges med udvidelse af sanseregistret fra syn til følelser, hørelse, den fælles tur med færgen. Jeg'et og ,the others" udgør et fællesskab. Afsnit 3 begynder med en konstatering af at „distance avails not" og understreger at fortid, nutid og fremtid bekræfter det sanselige fællesskab, og parallelle sætninger fortæller a 
"Just as any of you" ser, føler, står, forfriskes, gør Jeg'et det også. „Others“ $i$ afsnit 2 er blevet "you" $i$ afsnit 3 og er dermed rykket nærmere. Sanseiagttagelser fra sejlturen og Manhattan vælter in over Jeg'et $i$ et langt hukommelseskatalog $i$ afsnit Erindringen ligger altså ikke uden videre klar i be vidstheden, men udloses farst af idere klar i beid lesskab og ar in form af $d$ af Denne betingelse opsunm $i$ indledningen til a snit 4: "These and all else were to me the same a they are to you " (v. 4g). Derpas stopperde konkrete iagttagelser: „I stop here to-day and to-night" ( 53).

Omverdenen er gradvis blevet bygget op fra enkeltsansninger på afstand, lnyttet til synet, til me omfattende sansninger, der gradvis har knytte Jeg'et og andre mennesker og ting sammen på tvær af rum og tid, men med Manhattan og sejladsen som sanseligt udgangspunkt. Denne helhed bliver da genstand for en ny slags iagttagelse, nemlig refleksion, der allerede er foregrebet $i$ meditation sion, der allede er foregrebet i meditionerne i a ifremidsync $i$ fremtidssyn og erindring. Refleksionen slutter med konstateringen af koppen som omdrejningspunk "I too receiv'd identity by my body" (v. 63). Og he kunne digtet for så vidt også slutte.

Men det gør det ikke, for der er også en anden udviklingslinie der går på tværs af den første (som, i parentes bemærket, ofte er den eneste man not rer hos Whitman: fra omverdenserfaring til selvbe kræftelse). Sceneriet rulles op da der kun er en hal time til solnedgang (v. 2,17$)$. Det syn der åbner digtet har kun en halv time at virke i, så er det nat og Manhattan lukker og slukker for yderligere synsindtryk. Nattem rrket breder sig fra slutningen af fsn 3 til slutningen af afsnit 4 fra twiligh “ $(v, 43)$ 3 til slumgen af morker malner terhanden som lepskoncentratonen oges. Fra slut ningen af afsnit 3 bliver alting "dimmer and dimmer" og "shadowy. Lyset fra den anden side "Casting their flicker of black contrasted with wild red and yellow light over the tops of the houses into the clefts of the streets" (v. 48) - her ser man ikke noget $i$ lyset, men kun selve det springende kunstige lys i nattemørket. Så de sanseindtryk, Jeg og Du er fælles om (v. 49), er yderst ustabile.

Denne tendens underbygges af at tids- og rumhorisonten udvides fra faktiske sansninger til forestillinger om eller erindringer om sansninger. Frimodigt projiceres sanseindtrykkene hinsides ring d (v. g de kalder erindring frem i deres billede. Men gså erindringerne balancerer mellem klare sansinger pả den ene side: màgerne der svæver stille $\mathbf{i}$ luften, sømænd, master osv. (v. 23, 39, 40), og på den anden side bevirker slørede og konturløse sansninger at Jeg'ets øjne er „dazzled“: himlens reflekser i vandet, tåge, damp, lysglimt osv. (v. 30-35). Og går vi tilbage til de klare sanseregistreringer $i$ digtets begyndelse, viser de sig at være knyttet til fænomener der bestandig er $\mathrm{i}$ bevægelse, og at være „numberless" (v. 26).

Så den sikkerhed hvormed kroppen anbringes centrum, in $i$, sister ko por af sansninger, erindringer og ører og øjne, er det eneste der er, konstant. det er ike omverdenens

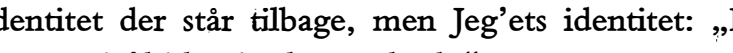
too receiv'd identity by my body".

2) sprog og subjekt: Set fra denne synsvinkel kan digtet naturligvis ikke slute ved slutningen af afsnit 5 . Der er dannet et kropsligt subjekt uden omverden at anbringe kroppen i. Digtets sidste del handler nu om hvorledes dette subjekt skaber sig en omverden gennem sproget, således at denne igen bliver tilxangelig som konkret falleserfaring. Ogso dette

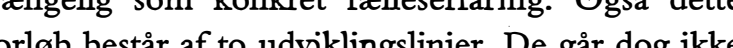
fog ikke pplerer hinante digtet.

Det er forst efter afsnit 5 at sproget optræder som en anden og mere omfattende kontaktform end sansningen. Her begynder sprogprocessen som udviklingen af sansningen slutter, nemlig diffust, men rbejder sig derpå frem mod præcision, altså en modsat udviklingen i forhold til sanseerfaringen. Sproget omtales først nærmest negativt: „blabb'd“, "I dared not speak“", ,the frivolous word“" (v. 72, 73,
76). 3 Først derefter åbner sproget for en dialog: „, $[1]$ Was called" med om ikke det helt rigtige navn sa dog „my nighest name“, og sproget er endnu ikke fuldt udviklet hos Jeg'et selv, der ,never told them a word“ (v. 78, 8I). Sidste skift før dialogen kan udaldes foldes het, kelig kon, er betrallesskab ved paralletle og ensartede sansninger som i forste fem afsnit, men som dialogisk udveksling. Nærheden i sanseuniverset, knyttet til kroppen, rejses som spørgsmål i afsnit $s:$ "What is it then between us?" (v. 54). Og svaret må være at det der ex mellem os, er den krop der på den ene side giver en fælleserfaring, og på den anden side markerer den distance der gør at Jeg og Du er sammen, men hver for sig, i hver sin krop - „I too" hedder det, men ikke ,we“": „I too had receiv'd identity by my body“ (v. 63). Nærheden gennem sproget er anderledes end gennem kroppen. Jeg og Du som kroppe udgor to ensartede parallelt eksisterende vesner, mens to ensar dens de gen i spoget. skab i en proces. Verbet andres fra "is “ (v. 54) "approach "s. "Closer yet I appoach you (v. 86), hedder det $i$ afsnit 7 , selv on vi har hort at "distance avails not "(v. 20, 56). Afsnittet slutter med spørgsmålet: „Who knows, for all the distance, but I am as good as looking at you now, for all you canno see me?" (v. 9I). Det sted hvor Jeg'et kan se på en anden uden at kunne blive set, er netop i sproget, hvor Jeg'et ser Du'et ved at omtale det.

På den baggrund fortsættes sporgsmålene i afsnit $8 \mathrm{i}$ genoptagelse af de tidligere sansninger, kulminerende i et afsluttende spørgsmål der genoptager digtets indledende møde ansigt-til-ansiot med ting og mennesker. Sporsomilet drejer og betydningsudveksling, ikke om sansning.

What is more subtle than this which ties me to the woman or man that looks in my face?

Which fuses me into you now, and pours my meaning into you?

We understand then do we not?

What I promis'd without mentioning it, have you no accepted?
What the study could not teach - what the preaching could not accomplish is accomplishe'd, is it not? (v. 96-100)

Trods de sidste linier går dialogen dog ikke her $u$ den om sproget slet og ret, men betydningsdannelsen går ud over sproget. Sporgsmålene forudsætter jo nemlig at Du'et ved hvad sprog er - nævne, studere, lere, pringer

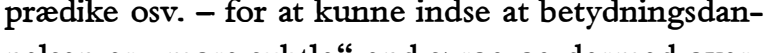
pres overskrider det. Men pa den anden side falder kommunikationen tilbage i sproget igen, i og med hele fremstillingen kun holdes åben ved at være formet som et spørgsmål. Enheden mellem Jeg og Du rejses som et spørgsmål i sproget, den sproglige form der netop rækker hinsides det sporgende subjekt og ud over sproget. Et spørgsmål bestemmer jo hverken hvem der svarer eller svarets art. Derfor er det sandt: noget "more subtle“ end denne situation findes ikke. Sproget hverken benævner eller besværger, når Whitman er bedst, men åbner.

I afsnit 9 genoptager og gentager digtet katalogopremsningen fra erindringen i afsnit 3 , men ud over tingene inddrager afsnit 9 også henvisningerne til forholdet mellem Jeg og Du i rollespil; sprog og kommunikation. Kataloget giver derfor udtryk for at der er en sanseerfaring hinsides sproget, men at den netop må formuleres i sproget hvis den skal opstå som fælles erfaring og placere Jeg og Du i den og $i$ forhold til hinanden: „Appearances, now or henceforth, indicate what you are" (v. 120). Kataloget henviser ikke til den virkelighed der er, men er et forsøg på at erobre virkelighed, ikke at beskrive den.

Det er den ene udviklingslinie i forholdet mellem sprog og subjekt: gennem det sprogbrugende subjekt generobes den omverden der gennem subjelt ger sennem sansding supplerer Dienter Digtet begynder med et observerende og autonomt Jeg på distance, „I see , og slutter med en anerkendelse af et Du pa samme niveau. „There is perfection in you also" (v. I vs v. 130). Hvad sker der indimellem?

Hvis man vil isolere de forskellige anvendelser a $\mathrm{Du}$ i teksten, giver det et noget flimrende billede af 
Du'ets identitet. Men ligesom sprogets rolle gradvis præciseres, gør Du' ets identitet det også. Sproget giver det den konturfasthed som sansningen fratager det. I sansningen er hvad som helst et $\mathrm{Du}$, blot Jeg'et retter sin opmærksomhed imod det. Det yder ikke modstand eller holdet Jeg'et fast men er blot et forbigionde objelt for Jeg'ts are eller aje. I det et foriger oje. I det korte afsict 1 andes det fat at vare et vilkărligt og udskifteligt sanseelement til at være en imaginær tekstkonstruktion og fremtidsfantasi. Først er Du'et identisk med "flood-tide" (v. r), med "Clouds of the West" (v. 2) og med "Crowds of men and women" (v. 3); derpå med en inaginær samtalepartner $(\mathrm{v} .4,5)$ og endelig med en anonym fremtidig færgerejsende der inkluderer den imaginære samtalepartner (v. s). Du'et bliver med andre ord hverken selvstændigt eller præcist blot af at blive påkaldt mange gange. Det er indbegrebet af omverdenen som produkt af Jeg'ets sansning og fantasi. En abstrakt 3. person mere end en 2. person.

Du'et forsvinder og optræder slet $i k k e$ i afsnit 2 hvor 3. personsformer som sher" ", $i$ arsnit 2 , hvor 3. personsfor "og "all things" tager pladsen. Da disse 3. persons enheder tranformeres til 2. persons Du i afsnit 3, er Du'et klart personificeret til at være én af massen som både ser, hører og gør det samme som Jeg'et og som kan tiltales, men $i$ alle tilfælde som én der er identisk med Jeg'et, én hvis erfaring og fortollming er den samme. Jeg og Du er begge generaliserede og tilfældige, sansende mennesker i mængden. I afsnit $s$ forenes de derfor $i$ et "us“. Denne forening sker det sted i teksstèn hrờ ợså kropsidentiteten slås fast som omdrejningspunkt for Jeg'ets identitet, og Du'et er her indirekte til stede i det gentagne „I too".

Men i afsnit 6 sænker mørket sig ikke blot over sceneriet efter solen er gået ned, så sansningen sløres. Mørket falder også på Jeg og Du: „It is not upon you alone the dark patches fall,/The dark threw its patches down upon me also" (v. 65f). Ligesom omverdenens konturer ikke længere kan trækkes op af sanseregistreringen, kan Jeg'ets og Du'ets ensartethed, der gør dem til et "we“ eller ",us“, heller ikke afklares blot ved at de kan se og høre hinanden. Kropsidentiteten giver ingen fælles forankring. De er nu fælles om at være helt eller delvis usynlige for hinanden.

Det er derfor ikke den fysiske barriere imellem dem der er vigtig, og som kan opfattes og overvindes med sanseapparatet $i$ konstateringen af at de er ens. Problemet er nu deres selvforståelse: tvivlen pà te (v) 69f), den proglige afragt eller fordrejing $(v .72)$ og med en lang række folelser og handlinger der ødelægger fallesskab. Ud af denne refeksion over hvad de hindrer fællesskab, vokser et "we“ (v. I26). Det er kke blot blevet til gennem passiv sansning af ting og mennesker, men ved den reflekterede bearbejdning som sproget og betydningsdannelsen muliggør. Og denne proces er gensidig: Jeg'et "fuses“, trænger ind i, Du'et med sin „meaning", og det modsvares af at Du'et "peruses“, gennemlæser, Jeg'et (v. 97 vs v II2); Jeg'et har forestillet sig det endnu ikke fødte $\mathrm{Du}$, og det modsvares af at Du'et forestiller sig

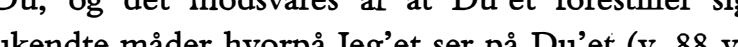
vit), fels. De Der ud( er sjalen (v. 121), som træder nâr Jeg er 1 stand til at forholde sig til alle Du'er som det sker i slutningen (v. 130-32).

Jeg og $\mathrm{Du}$ er diskursive instanser, nødvendige for hinanden og forskellige fra hinanden og omfatte dermed også de steder hvor Jeg og Du lever. Byen apostroferes: „Thrive, cities“" (v. I23). Den samtidighed af forskelligartede ting og mennesker Whitman proklamerer som det nationale særpræg, fảr dermed ikke kun en tematisk representation $i$ teksten, men er integreret $i$ tekstens diskursive strategi. Færon er ejlet fi Jeg til Du og dermed genn. Færge har sejlet fra Jeg

Men over for dette ,we“ står der endnu et Du: we receive you with free sense at last" (v. I27). De er "the dumb [...] ministers" som Whitman $i$ en overbærende gestus tager til nåde i slutiningen af af snit 9 . Han ser dem endog som „beautiful“" og med "perfection" (v. 126, I30), skønt det jo er dem hvi prædiken, løfter og studeringer er blevet afvist som banale (v. roo), fordi - det er min tolkning - de netop blot omtaler fæellesskab, men ikke, som Whitman, i deres sprog skaber det. Men også de kan n integreres, simpelthen ved at blive integreret $i$ Whitmans diskurs og dermed genskabt som et nyt $\mathrm{Du}$ : "we use you, and do not cast you aside - we plan you permanently within us" (v. I29). Nu er både store og små ånder blevet del af folloskabet sprogets sensiline sprogets genidige udvelsing han ningens og den udide ikke for at overskide den, men for at genindsætte subjekterne $i$ den $-i$ den komplekse, ekspanderende, driftige by, det sted der er alle steder på é gang. Som national poet er Whitman en urban poet.

Sprog, subjekt, sted

Det sproglige subjekt er $i$ teksten bygget oven på det kropslige, således at det kropslige subjekts isolered erfaring, begrænset af kroppen og nattemørket os dets flimrende lys, i sproget forankres som falleserfaring. Dette dialogiske syn på sproget er indehold i det jeg henviste til ovenfor som Whitmans visio" vision " teriske prefter of ideologisk langt mere i fanlie med den tidige, til dels samtidige ame ilkanse pragnaters Peirce, William James, Herbert Mead, John Dewey) end med europæisk nationalisme og romantis sprogopfattelse, trods overfladisk lighed i diktione og selv om man fra Emerson kan se i begge retninger (cf. note 2)

Whitmans digte indskriver altid en modtager, et ikke-Jeg, som betingelse for Jeg'ets dannelse : ,Je lægger min hånd på dig, så du kan blive mit digt (Whitman 1990: 186). Subjektet befinder sig altid i en overgang mellem sig selv og en anden, og skaber derigennem, uafladeligt, det sted hvor de begge nye nationale virkeligheds ingrediens bebudet af min stemme - jeg vil ikke sove længere, men rejse mig“" (ib.: 28). Derfor synger Whitman $i$,Song og Myself $f^{\prime}$ ikke on Jeg'et, men synger det, dvs. skaber det ved at syng "Jeg fejrer migselv, og synger migselv" (ib.: 29). Det er i dette lys de to store kataloger skal ses: afsnit 3 er kataloget en sansebaseret rekonstruktio af erindringen der i sproget formes på nutidens be- tingelser, men ikke beskriver nutiden; i afsnit 9 er kataloget en verbalisering af det betydningsfællesskab der $i$ afsnit 8 endnu er ubenævnt (v. 99), en indlemmelse af fremtiden (,Flow on“, „Frolic on“" „men and women after me“" osv. (v. rorff)) på nutidens betingelser, men ikke en beskrivelse af nutiden. Disse kataloger, sivel som Whitmans talrige andre, beskriver ikke de forligen Disse og stedab in De skaber heller ilke ingene 1 tid og rum med magisk besværgende pákaldelse. Men de skaber de eksisterende tings samtidighed og sameksistens med hinanden og med os. Katalogerne er et eksperiment $i$ at få greb om en verden der ellers flimrer væk, ikke en beskrivelse af dens dagklare tingslighed. "Realisme foranlediget af realitetstab", som Adorno siger om Balzacs tætte tingsbeskrivelser (Adorno 1973: 30). Katalogerne skal ses fra de diskursive processer, ikke omvendt.

Ikke stedets stabilitet er i fokus, men dets overskridelse, ikke det fremmedes reduktion, men dets tilstedeværelse, ikke sproget som suverænt selvudtryk eller kollektivt nationalt medium, men som medium for subjektiv gensidighed. Det er ikke den identitet der foreligger der er i centrum, men den identitetsproces der er mulig. Sammenhæng mellem sted, menneske og sprog er ikke givet, men skal nyformuleres. Hele tiden. For fuld fart. Overfart.

Noter

r. Digtet lases efter Walt Whitman: Leaves of Grass. Oxford: Oxford University Press (The World's Classics) 1990, I29-I34, optrykt efter den sidste udgave i 1891/92. Digtet udkom forste gang i 2 . udgaven fra 1856 af Leaves
of Grass under titlen „Sun-Down Poem“", skiftede navn til "Crossing Brooklyn Ferry" $i_{3}$. udgaven i 1860 og beholdt derefter navnet, mens der skete mindre tekstændringer undervejs til 1871 efter 4 . udgave i 1867 og 5 . udgave i 1870. Endelig version $i$ 6. udgaven i $188 \mathrm{I}$ og $i$ den sidste udgave 1 1 $891 / 92$. Om variantapparat, se Sculley Bradley rum of the Printed Poems. Volume I. Poems I Is5-1856. New York: New York University Press 1980. 217-225. - Jeg citerer fra digtet med henvisning til verslinie: $(\mathrm{v} . \mathrm{xx})$, der svarer til oversettelsen ved Karsten Sand Iversen der findes efter artiklen. Øvrige citater er oversat af mig. 
2. I de tre store afhandlinger om Whitmans sprog redegøres der for paralleller til moderne lingvistik og talehandlingsanalyse (Hollis 1983), ligesom vagten pa kommunikation frem for exspression $i$ dannelsen af det

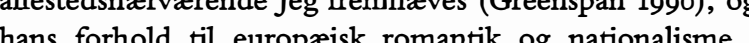
sprogopfattelse og sprogbrug trekkes frem sammen med påvirkningen fra Fmerson (W/arren 1990). Men ejendommeligt nok opridses der ingen paralleller mellem Whitman og den amerikanske pragmatism/pragmaticisme, der også har taget vejen om ad Emerso

3. Måske indholder "hearings" og "hearing of others " også sprog, men det er selve lydindtrykket der er afgorende her til forskel fra ,"sights og "sight $($ V. 9,12$)$. Ogsa ithin me" (v. 59$)$.

Litteratur

Adorno, Theodor (1973). Noten zur Literatur II. Frankfurt A.M.: Suhrkamp

Aristoteles (I9I5). Ethica Nicomechea. The Works of Aristotle translated into English 9. Oxford: Oxford University Press. Aristoteles (1930). Physica. The Works of Aristotle translated into English 2. Oxfor

Bachelard, Gaston (1958). La poétique de l'espace. Paris

Boelhower, William (1984). Through a Glass Darkly Ethnic Semiosis in American Literature. Oxford: Oxford UP.

Coffman, Stanley (1974). „Crossing Brooklyn Ferry“: A Note on the Catalogue Technique in Whiman's Poetry Arthur Golden (ed.): Walt Whitman. New York: McGrawHill. 6I-71.

Cook, Albert (1998). Space and Culture. New Literary History 29. 55I-572.

erson, Ralph Waldo (r98r). The Portable Emerson. New York: Viking Peguin.

Fairschild, Hoxie Neale (Ig6I). The Noble Savage. A Study in Romantic Naturalism. New York: Russell \& Russell. Galilei, Galeo (1962). Dialogue Concerning the Two Chif World SYstems. Berkeley: University of California Press. Greenspan, Ezra (1990). Walt Whitman and the American Reader. Cambridge: Cambridge University Press.

Greenspan, Ezra (ed.) (199s). The Cambrage Companion to Whit

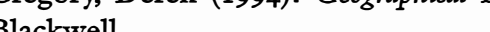

. Made in the U.S.A. The Construc

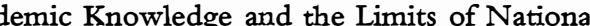
Culture. Poetics Today 19/3. 335-356.
Hollis, Charles Carroll (1983). Language and Style in LeaBaton Rouge: Louisiana State U.

Johnston, John (I984). The Poet and the City. Athens: The University of Georgia Press.

Walt Whitman. New York

Lang, Helen (I995). Aristotle's Physics IV,8. Journal of the History of Ideas 56/3. 354-376.

Larsen, Svend Erik (1996). Naturen er ligeglad. Naturopfat-

Larsen, Svend Erik (1997a). Storbyen tværs over Atlanten Anglo files 97/ 104. 12-19.

(997b). Landskab, hjemstarn, histoiie. K. Elberg \& J. Guldberg. (eds.): Hjemstavn. Odense: Odeng. 73-86.

Sv.E. Larsen \& A.B. Petersen (eds): Odense: Odense University Press. I4-63.

Larsen, Svend Erik (1998). The National Landscape Cultural European Invention. A. Odendaal \& M. Palmberg.(eds.): National Identity and Democracy, Cape Town

Maibuy Center (i trykken).
Lorsch, Susan ( 1983$)$. Where Nature Ends. Literary Response to the Designification of Landscape. London/Toronto: Associed

. Bekenntrise des Hochstaplers Felix Krull. Frankfurt a.M.: Fischer.

Pauly (I9ro). Paulys Realencyclopädie der classischen Altertumswissenschaft VII,I: Genius. Stuttgart: Metzler. II55-II70. Pke, Burton (I98I). The Image of the City in Modern Litevature. Princeton: Princeton University Press.

Shumway, David R. (1998). Nationalist Knowledges: $\mathrm{H}$ manities and Nationality. Poetics Today 19/3. 357-373. Simmel, Georg (1968). Soziologie. Berlin: Duncker

Than,-Xi-Fu_(1977). Space and Place. The Perspective of Experience. Minneapolis: The University of Minnesota Press.
Warren, James Perrin (1990). Walt Whitman's Language Ex periment. University Park: Pennsylvania State UP.

Whitman, Walt (I965). Democratic Vistas. Le and Selected Prose. New York Holt, Rinehart and Winston.

489-546.
Whitman, Walt (1980). Walt Whitman. Leaves of Grass. A Textual variorum of the Printed Poems. Volume I: Poems, I8551856. New York. New York University Press.

xford: Oxford Orsted, Hans Christian (1852). Om Danskhed. Samlede of efferladte Skrifter 7. København: A.F. Høst. 39-58. 